\title{
Internal structure and development of an aeolian river dune in The Netherlands, using 3-D interpretation of ground-penetrating radar data
}

\author{
R.L.Van Dam \\ Netherlands Institute of Applied Geoscience TNO, PO Box 6012, 2600 JA Delft, \\ The Netherlands \\ Currently at: Geopuls, Bemuurde Weerd o.z. 7, 3514 AN Utrecht, The Netherlands; \\ e-mail:remke@geopuls.nl
}

Manuscript received: January 2001; accepted: January 2002

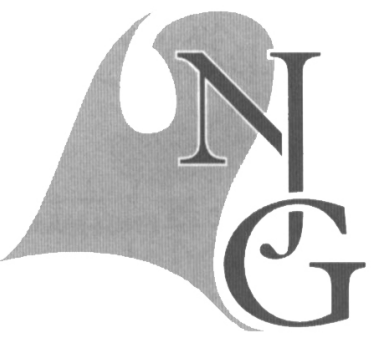

\begin{abstract}
Ground-penetrating radar data from a regular grid are used to study the internal structure and development of a 9-m high aeolian river dune in the Dutch Rhine-Meuse delta. The purpose of this investigation was to image the internal sedimentary structures to better understand the development of these aeolian river dunes. Three radar facies can be recognised in the GPR sections. Radar facies 1 has a maximum thickness of 5 to $6 \mathrm{~m}$ and is characterised by dipping, parallel reflections with a maximum length of at least $20 \mathrm{~m}$. The reflections from perpendicular sections, analysed using closed-loop correlation in 3-D-interpretation software, form eastward dipping ( $14^{\circ}$ maximum) surfaces. Radar facies 2 is one continuous, sub-horizontal reflection. This high amplitude reflection is most probably caused by a thin organic horizon. Radar facies 3 has a thickness of 3 to 4 $\mathrm{m}$ and is made up of sets of short, predominantly eastward to north-eastward dipping reflections separated by rather continuous, sub-horizontal reflections. The eastward dipping surfaces in radar facies 1 are foresets of a dune that was deposited by prevailing westerly winds in the Younger Dryas, the last cold period in the Pleistocene. During the Early Holocene, an increasing vegetation cover stabilised the dune and formed a thin organic horizon. Subsequent resumption of dune forming processes led to the formation of radar facies 3 on top of the vegetated Pleistocene dune. Sedimentation by small dunes, partly eroding each other, led to sets of cross-stratification separated by bounding surfaces. The results suggest a small change in palaeo wind direction.
\end{abstract}

Keywords: aeolian, ground-penetrating radar, palaeo wind direction, Rhine-Meuse delta, three-dimensional imaging

\section{Introduction}

Understanding the processes controlling the development of aeolian dunes is important in fields such as sedimentology, palaeoclimatology, aquifer characterisation and groundwater studies. In the study of modern aeolian sediments, trenches allow for the careful and semi three-dimensional examination of sedimentary structures. In this way, very detailed reconstructions of processes and geomorphology have been made in the past (e.g. McKee, 1966; McKee \& Bigarella, 1979; Ahlbrandt \& Fryberger, 1980). Major disadvantages of this method are its time ineffectiveness and the need for disturbing the subsurface, which is not always possible or desirable. Groundpenetrating radar (GPR) has become an important method for the high-resolution study of the shallow subsurface without the necessity for excavation (Daniels et al., 1988; Davis \& Annan, 1989). The excellent possibilities of GPR for the imaging of sedimentary structures in aeolian dunes, were shown by Gawthorpe et al. (1993), Schenk et al. (1993), Bristow et al. (2000a), and Bristow et al. (2000b). Although various studies demonstrate the usefulness of GPR in obtaining accurate three-dimensional (3-D) information of sedimentary environments (Bridge et al., 1995; Bristow, 1995; McMechan et al., 1997; Anderson et al., 1999; Asprion \& Aigner, 1999; Beres et 
al., 1999; Pedley et al., 2000), 3-D imaging of aeolian sediments has been limited to work by Bristow et al. (1996).

In this study, GPR data are presented that show sedimentary structures in three dimensions within an aeolian river dune, the Hazendonk, in the western part of The Netherlands (Fig. 1). The dune is part of an elongated complex of so-called aeolian river dunes near Molenaarsgraaf (Verbraeck, 1983). Earlier research in similar dunes illustrated the possibilities of GPR to image sedimentary structures, even below the water table (Van Overmeeren, 1998). The mediumsandy $(210-300 \mu \mathrm{m})$ Hazendonk is underlain by a stiff clay and has a total height of $9 \mathrm{~m}$. The flanks of the dune are covered by Holocene clays and peat, leaving an area of about 100 by $50 \mathrm{~m}$ exposed at the surface (Louwe Kooijmans, 1974). The present elevation difference in the field of around $1 \mathrm{~m}$ is caused by compaction of the fine-grained sediments flanking the dune. We selected the Hazendonk for study because it is one of the most western unburied aeolian river dunes in the Netherlands and because of its presence in (mainly archaeological) literature (e.g., Louwe Kooijmans, 1974). Because of the shallow

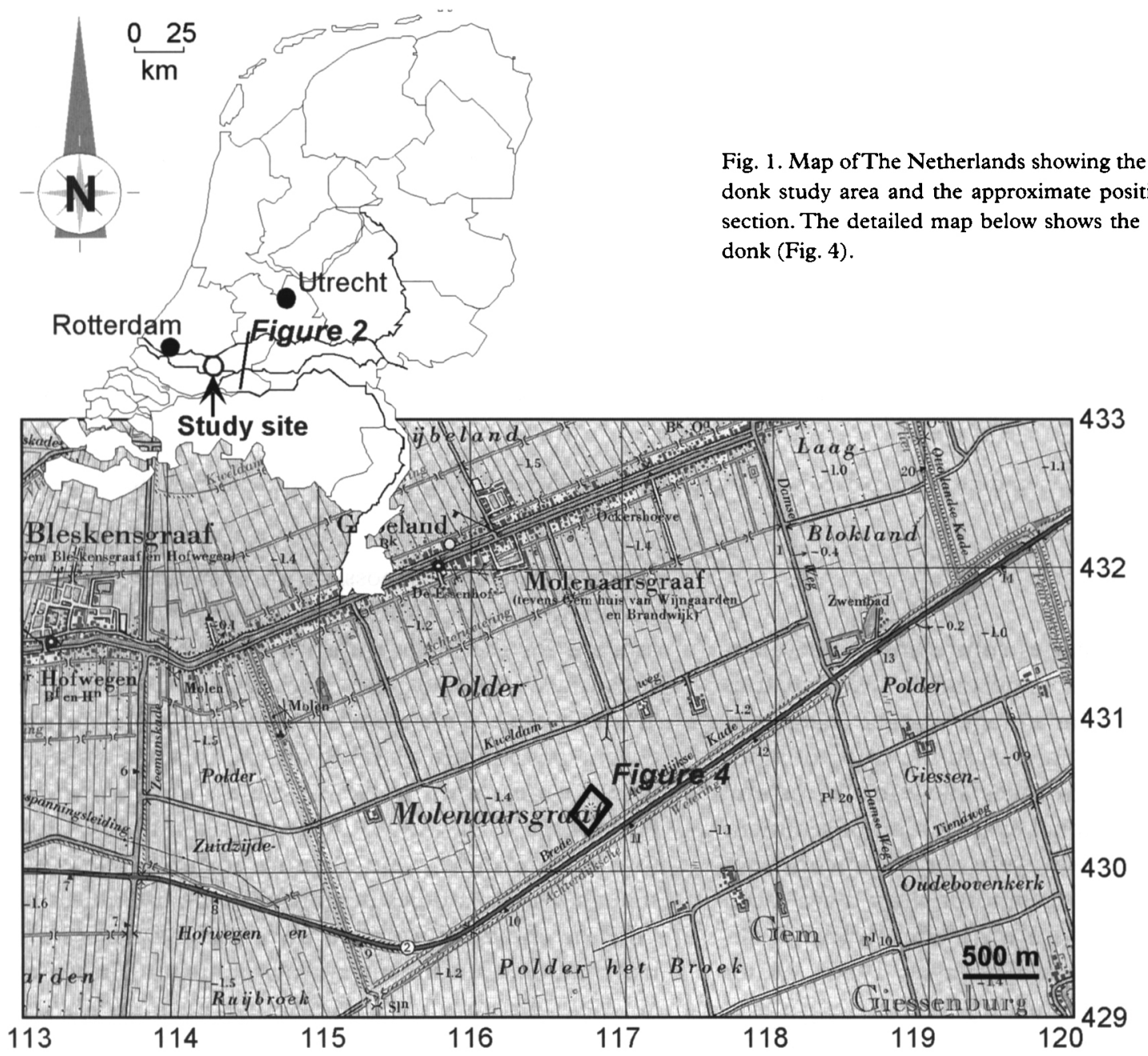
onk (Fig. 4) groundwater table (approximately $1.25 \mathrm{~m}$ deep) and the intensive agricultural land use, verification of the findings via trenches is impossible. Instead, a 3-D seismic visualisation program is used to facilitate and improve the interpretation of GPR data.

\section{Geologic setting}

During most of the last glacial (Weichselian), braided rivers deposited coarse-grained sediments in a wide alluvial plain, forming the Kreftenheye Formation. The climatic change from the last ice age to the warmer Holocene occurred in 2 steps, the BøllingAllerød and the Younger Dryas (Törnqvist, 1998). During the Bølling-Allerød, an interstadial with a warmer climate, the river pattern changed from braiding to meandering (Berendsen et al., 1995). Initially, the meandering rivers deposited fine-grained overbank sediments (up to $0.5 \mathrm{~m}$ thick) on top of the Kreftenheye Formation (Fig. 2a), but a reduced sediment supply due to the rapid warming caused the rivers to incise, resulting in terrace formation (Törnqvist, 1998).

A combination of wind activity (providing sand

the location of the Hazensection. The detailed map below shows the location of the Hazen- 


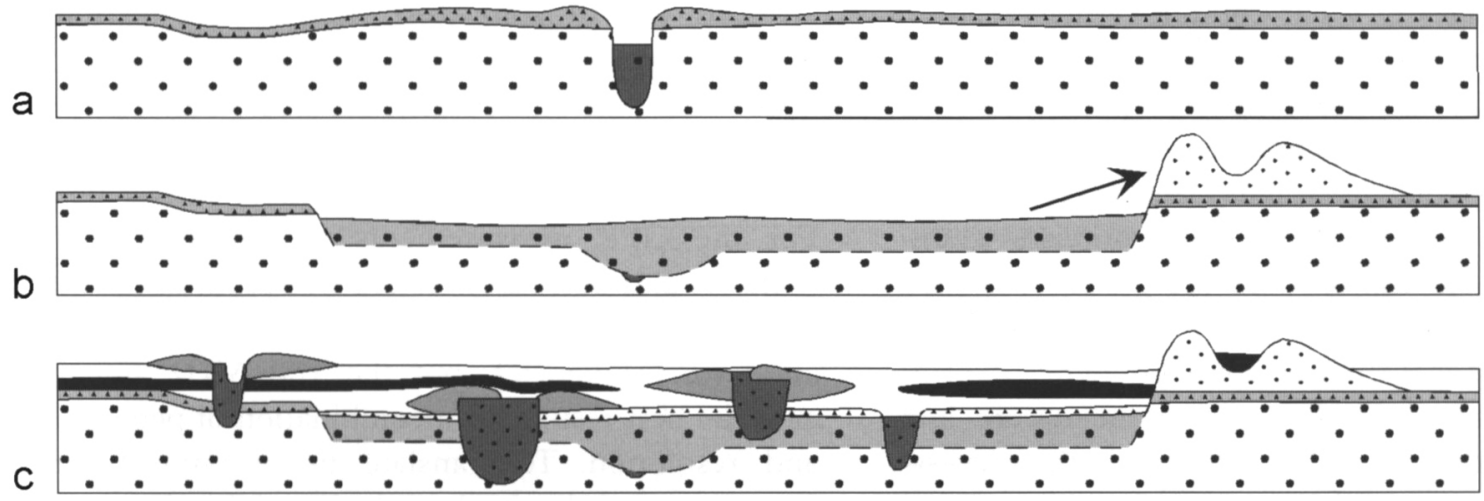

\begin{tabular}{|c|c|}
\hline Pleistocene & Holocene \\
\hline Mid\&Late-Pleistocene & Channel deposits - sand \\
\hline- Channel deposits - sand and gravel & $\therefore$ Overbank deposits - clay and sand \\
\hline Bølling - Allerød & $\square$ Overbank deposits - silt \\
\hline - Channel deposits - sand and gravel & $\square$ Overbank deposits - clay \\
\hline$\therefore$ Overbank deposits - clay and sand & Organic deposits - peat \\
\hline Younger Dryas & \\
\hline - Channel deposits - sand and gravel & $2 \mathrm{~km}$ \\
\hline$\because$ Aeolian deposits - sand & \\
\hline
\end{tabular}

Fig. 2. Schematic cross section showing the development of the Dutch Rhine-Meuse delta since the Late Weichselian: a) Bølling-Allerød, b) Younger Dryas, and c) Holocene. After Berendsen et al. (1995).

from riverbeds that were dry in winter) and bioturbation caused the overbank sediments to become bimodal in their grain size distribution. Owing to the long subaerial exposure and soil formation, the clay layer became stiff and commonly dark coloured, forming a very distinct stratigraphic layer in the Kreftenheye Formation, the Wijchen Member (Törnqvist et al., 1994). During the colder Younger Dryas stadial, when the rivers started to braid again, the terrace banks were eroded laterally. During winters, poorly sorted fine to coarse sand was blown up from the dry riverbeds by prevailing south-westerly winds, transported over short distances and deposited on top of the Bølling-Allerød Wijchen Member as aeolian river dunes, which occur as elongated complexes or individual members (Fig. 2b). The sedimentation was influenced by vegetation, reflected in the parabolic shape of various dunes (Verbraeck, 1983). In the Holocene, dune formation resumed locally (Pons, 1957).

At the Pleistocene-Holocene transition the river pattern changed to meandering once more and a
Wijchen Member similar to that present in the Bølling-Allerød period was formed. Influenced by rising sea level, the rivers started to aggrade in the Early Holocene. In time, the Wijchen Member was covered with overbank deposits, dissected occasionally by newly formed channels that originated from avulsions upstream (Fig. 2c). In the eastern part of The Netherlands the Holocene cover is thin, therefore leaving large dune areas unburied. In the western part of The Netherlands, the Holocene fluvial sequence reaches a maximum thickness of $15 \mathrm{~m}$, covering most of the dunes. The uncovered parts are named 'donk' in Dutch, explaining the name of the Hazendonk.

\section{GPR theory}

Ground-penetrating radar is based on transmitting electromagnetic energy into the subsurface (Fig. 3). Changes in electromagnetic wave impedance $(Z)$ in the sediment cause part of the transmitted electromagnetic energy to reflect back to the surface (Davis \& Annan, 1989; Jol \& Smith, 1991). These variations 
in electromagnetic wave impedance are mainly caused by changes in water content (Huggenberger, 1993). Water content in unsaturated sediment may depend on a number of textural properties such as grain-size and pore-size distributions, total porosity, diagenetic iron-oxide precipitates, and the presence of organic matter (Van Dam, 2001). Variations in grainsize and pore-size distributions are generally related to the sedimentation process. As a result, GPR reflections frequently show a close correspondence to sedimentary structures. Understanding the nature and origin of the radar reflections is crucial in the successful interpretation of GPR images.

Radar facies analysis is a method for the description and interpretation of GPR images, using differences in reflection pattern (Gawthorpe et al., 1993; Van Heteren et al., 1998). Radar facies are defined as the sum of all characteristics of a reflection pattern in a GPR image, as produced by a specific sedimentary succession (Van Overmeeren, 1998). These visible characteristics or elements thus are the result of all sedimentary features in the subsurface that influence the GPR response. The main facies elements used in radar facies analysis are amplitude, continuity and configuration of reflections and the external geometry of radar facies units.

\section{Data set and processing}

On the dune, 21 radar sections were sampled in a reg- ular grid, with a spacing of $8 \mathrm{~m}$ (Fig. 4, Table 1). Seven north-east to south-west oriented sections follow the long axis of the dune at the surface, whereas 14 north-west to south-east oriented sections lie perpendicular to this axis. four survey lines (two in each direction) were added to achieve more lateral detail. For the GPR measurements a pulse-EKKO 100 (Sensors and Software) system was used. Initial measurements were made with $25,50,100$ and $200 \mathrm{MHz}$ antennae frequencies, but the $100 \mathrm{MHz}$ antennae gave the best results for a combination of penetration and resolution. To translate two-way-travel times (twt) to actual depth, the velocity of the signal must be known. To acquire these velocities common-midpoint (CMP) measurements were conducted at the conjunction of the radar lines 7 and $G$ in north-east to south-west and north-west to south-east direction (Fig. 4, Table 2). To enable further verification of the GPR data four hand drillings were performed (Fig. 4).

The CMP measurements revealed a wave velocity of $0.133 \mathrm{~m} / \mathrm{ns}$ for the part above the groundwater table. The velocity between the groundwater table and a prominent sub-horizontal reflector at a depth of $100 \mathrm{~ns}$ twt deep was determined using the Dix (1955) formula and was found to be $0.085 \mathrm{~m} / \mathrm{ns}$ (Table 2). As most interesting features occur below the water table, the latter value was used for a depth scale on the radar sections. The vertical resolution, which approximately equals a quarter of the wavelength (e.g. Van Heteren et al., 1998), is controlled by both veloc-

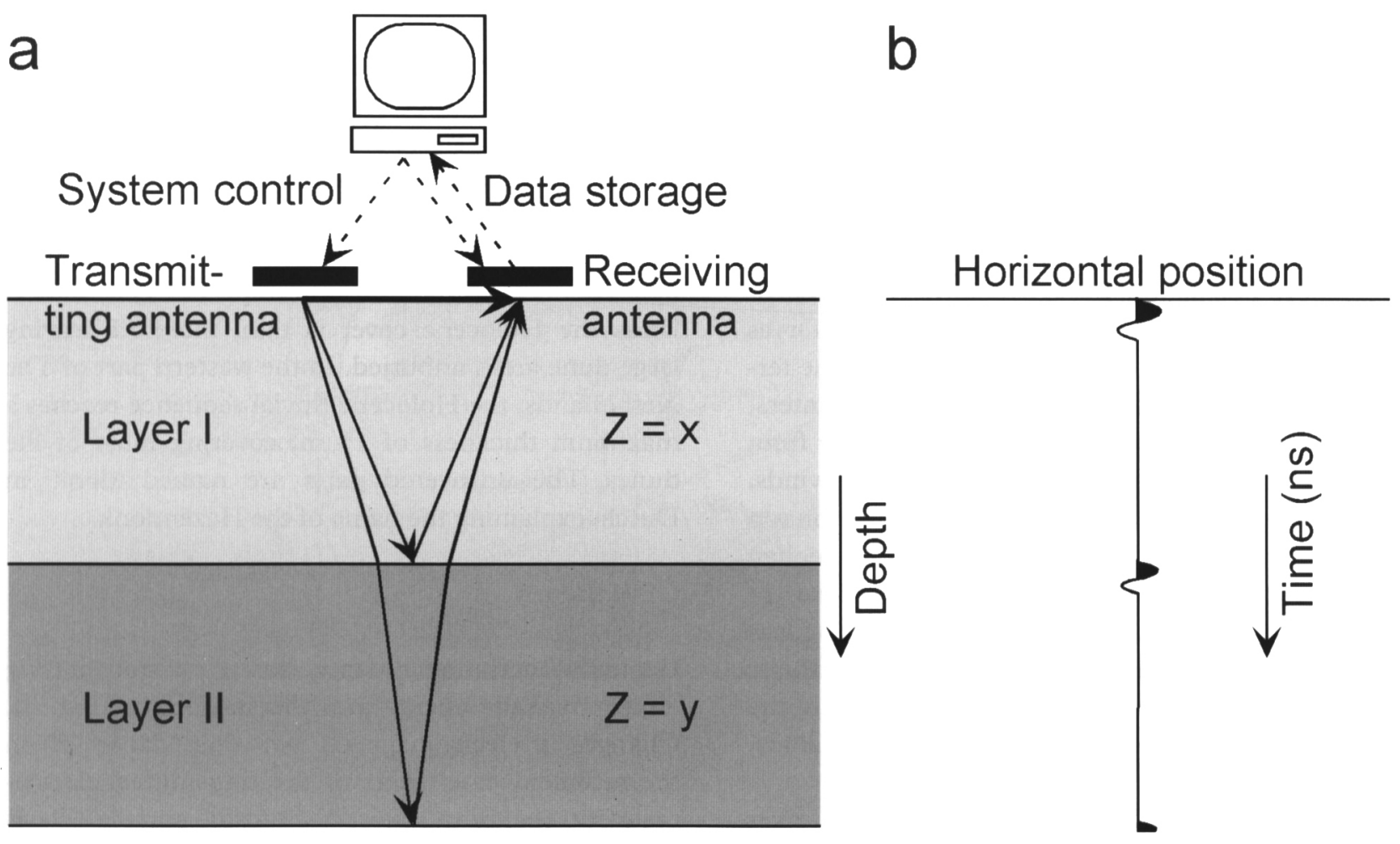

Fig. 3. The ground-penetrating radar method: a) configuration, and b) resulting radar trace. After Van Dam \& Schlager (2000). 
Table 1. Overview of dimensions and locations of the $100 \mathrm{MHz}$ radar sections on the Hazendonk. The numbered sections trend north-east to south-west along the long axis of the dune; the lettered sections lie perpendicular to these (see Fig. 4). For all sections a step size of $0.25 \mathrm{~m}$ was used.

\begin{tabular}{|c|c|c|c|c|}
\hline Section & $\mathrm{Y}(\mathrm{m})$ & $\mathrm{X}_{0}(\mathrm{~m})$ & $\mathrm{X}_{\max }(\mathrm{m})$ & Length (m) \\
\hline 1 & 10 & 18 & 90 & 72 \\
\hline 3 & 18 & -9 & 90 & 99 \\
\hline 5 & 26 & -5.5 & 94 & 99.5 \\
\hline 7 & 34 & 0 & 98 & 98 \\
\hline 6 & 36 & 26 & 34 & 8 \\
\hline 8 & 38 & 26 & 34 & 8 \\
\hline 9 & 42 & 5.5 & 103 & 97.5 \\
\hline 11 & 50 & 12 & 107.5 & 95.5 \\
\hline 13 & 58 & 16 & 113 & 97 \\
\hline Section & $\mathrm{X}(\mathrm{m})$ & $\mathrm{Y}_{0}(\mathrm{~m})$ & $\mathrm{Y}_{\max }(\mathrm{m})$ & Length (m) \\
\hline $\mathrm{Z}$ & -6 & 0 & 72.5 & 72.5 \\
\hline A & 2 & 0 & 72 & 72 \\
\hline $\mathrm{C}$ & 10 & 0 & 72 & 72 \\
\hline $\mathrm{E}$ & 18 & 0 & 72 & 72 \\
\hline $\mathrm{G}$ & 26 & 0 & 73 & 73 \\
\hline $\mathrm{F}$ & 28 & 1 & 72 & 71 \\
\hline $\mathrm{H}$ & 30 & 3 & 72 & 69 \\
\hline I & 34 & 0 & 72 & 72 \\
\hline $\mathrm{J}$ & 42 & 0 & 72 & 72 \\
\hline W & 50 & 0 & 72 & 72 \\
\hline $\mathbf{K}$ & 58 & 0 & 72 & 72 \\
\hline $\mathrm{M}$ & 66 & 0 & 72 & 72 \\
\hline $\mathrm{O}$ & 74 & 0 & 68 & 68 \\
\hline$Q$ & 82 & 5 & 74.5 & 69.5 \\
\hline $\mathrm{S}$ & 90 & 17 & 73 & 56 \\
\hline $\mathbf{U}$ & 98 & 34 & 72 & 38 \\
\hline
\end{tabular}

ity and frequency. For a velocity of $0.085 \mathrm{~m} / \mathrm{ns}$ and an antenna frequency of $100 \mathrm{MHz}$, the radar signal may resolve features with a thickness of $0.2 \mathrm{~m}$. However, the rapid attenuation of high frequency components of the signal cause the centre frequency of the received signal to decrease with depth. As a result, the resolution of the signal decreases with depth.

To ensure optimal comparison among different GPR lines, the same processing procedure was applied to all sections. This processing included a timezero correction to line up the first arrivals, a correction for low frequency noise, and trace averaging in both time and space to minimise high frequency noise. To get an optimal representation of both strong and weak reflections, a multiplication factor, inversely proportional to the average signal strength over a certain time interval (AGC gain), was applied to the data. Also, the radar data were corrected for surface topography. For 3-D analysis of the data in GOCAD, the radar images were converted to a seismic-standard seg-y format and further processed with PROMAX.

\section{Results}

A typical example of a radar section on the Hazendonk is shown in Fig. 5. The difference in penetration between the dune and its flanking areas is striking. The dune sand has a relatively low attenuation as compared to the peat and clays on its flanks. However, the base of the dune at a depth of about $9 \mathrm{~m}$ (a two-way-travel time of about $210 \mathrm{~ns}$ ) cannot be seen with any of the antennae frequencies. The two parallel and continuous reflectors at the top of the section are caused by the overlap of direct air and ground waves. Between 28 and $42 \mathrm{~m}$ a small separation in the lowermost of the two bands can be seen. This is probably caused by interference with the water table reflection. Flanking the dune, a series of 3 to 4 parallel bands is present. Here, the low wave velocity in the peat and clays causes a downward time shift of the ground wave.

The sedimentary structures in the dune can be divided into 3 different radar facies units (Fig. 6). The lowermost unit is made up of parallel, dipping reflectors. On top of these, a continuous, sub-horizontal reflector is present at a depth of about $100 \mathrm{~ns}(\sim 4.25$ $\mathrm{m})$. Numerous discontinuous and sloping reflectors dominate the topmost unit.

\section{Radar facies 1}

The parallel, dipping reflections are mainly present in the north-eastern part of the dune. In the numbered profiles they dip to the north-east, in the lettered profiles to the south-east. In some cases they are horizontal at the top before they start dipping (Fig. 6 at 24 $\mathrm{m})$. The reflections have a maximum length of $20 \mathrm{~m}$. The length of the sedimentological features causing the reflections may be even larger since the weak signals prevent them from being traced further down. The reflection separation averages $0.5 \mathrm{~m}$. Using closed-loop correlation in GOCAD, the reflections were traced and combined in crossing radar lines to form 3-D surfaces (Fig. 7). A total of 9 surfaces, all dipping to the east at a maximum angle of $14^{\circ}$, were recognised and interpreted as foresets. The foresets reach sizes up to $400 \mathrm{~m}^{2}$, as is the case for the redcoloured foreset in Fig. 7. The eastern dip direction of the foresets suggests a westerly wind direction and is in harmony with the prevailing westerly and southwesterly winds during the Younger Dryas in The Netherlands according to Isarin et al. (1997).

\section{Radar facies 2}

The continuous, sub-horizontal reflection is present 


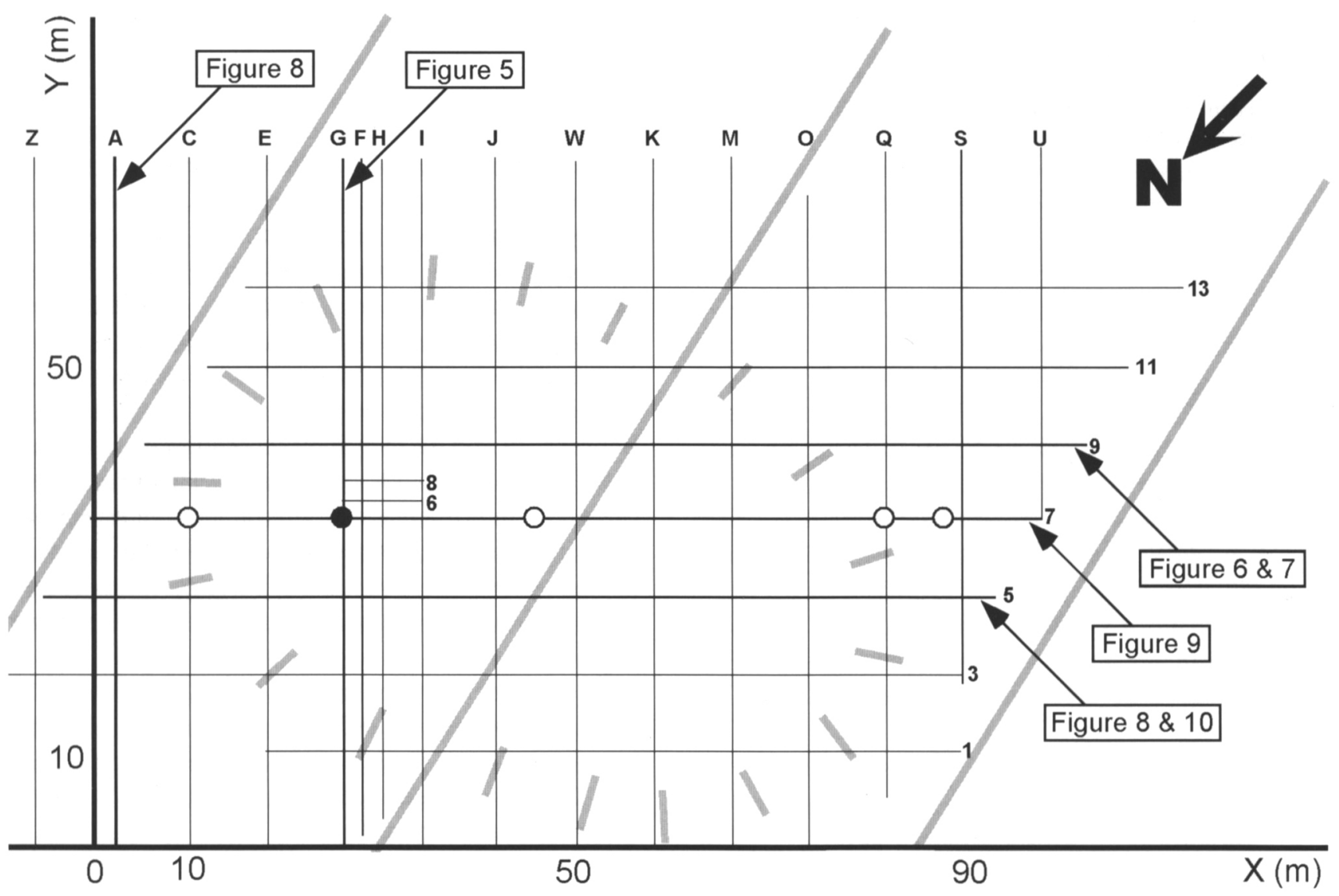

Fig. 4. Configuration of GPR sections, CMP measurements (closed circle), and hand drillings (open circles) relative to the measurement grid (thick black lines) on the Hazendonk. Numbered sections follow the long axis of the dune at the surface, whereas the lettered sections lie perpendicular to this axis. The three parallel grey lines represent ditches and fences; the shorter grey lines mark the approximate limits of the exposed part of the Hazendonk.

in all the radar sections. Closed-loop correlation and kriging interpolation in GOCAD show that the reflections in all sections form a continuous, slightly undulating surface; higher in the north-east and south-west and lower in the central part of the dune (Fig. 8). The reflection is relatively high in amplitude as compared to the reflections below and above this horizon, as is illustrated in Fig. 9. The change in electromagnetic wave impedance of this reflector is significantly greater than that associated with the other reflectors in the dune. As no distinct grain-size changes were observed in any of the auger drillings, this indicates that a feature other than a sedimentary structure must cause this reflection. As the surface appears to cap the sedimentary structures of radar facies 1 (see Fig. 6, at positions 5 to $25 \mathrm{~m}$ ) the reflector may represent a stabilisation surface. Because organic matter has different water-retention characteristics than clean sand, soils are excellent reflectors of electromagnetic energy (Van Dam et al., 2002). An organic-

Table 2. Overview of common-mid-point measurements and results for velocity calculations. All measurements were performed at the point $\mathrm{X}, \mathrm{Y}=26,34$ in two perpendicular directions. $\mathrm{V}_{1}$ is the velocity to the groundwater level, $\mathrm{V}_{2}$ is the velocity to a prominent reflector at approximately $100 \mathrm{~ns}$ depth and $\mathrm{V}_{\mathrm{int}}$ is the interval velocity.

\begin{tabular}{|c|c|c|c|c|c|c|c|c|c|}
\hline $\begin{array}{l}\text { Frequency } \\
(\mathrm{MHz})\end{array}$ & $\begin{array}{l}\text { GPR } \\
\text { section }\end{array}$ & $\begin{array}{l}\text { Step } \\
\text { size (m) }\end{array}$ & $\mathrm{X}_{0}(\mathrm{~m})$ & $\mathrm{Y}_{0}(\mathrm{~m})$ & $\mathrm{X}_{\max }(\mathrm{m})$ & $\mathrm{Y}_{\max }(\mathrm{m})$ & $\begin{array}{l}\mathrm{V}_{1} \\
(\mathrm{~m} / \mathrm{ns})\end{array}$ & $\begin{array}{l}\mathrm{V}_{2} \\
(\mathrm{~m} / \mathrm{ns})\end{array}$ & $\begin{array}{l}\mathrm{V}_{\mathrm{int}} \\
(\mathrm{m} / \mathrm{ns})\end{array}$ \\
\hline 50 & 7 & 0.5 & 0 & - & 27.5 & - & - & 0.1 & 0.09 \\
\hline 50 & G & 0.5 & - & 0 & - & 27.5 & - & 0.1 & 0.09 \\
\hline 100 & 7 & 0.25 & 0 & - & 11.5 & - & - & 0.095 & 0.082 \\
\hline 100 & $\mathrm{G}$ & 0.25 & - & 0 & - & 11.5 & 0.15 & 0.09 & 0.076 \\
\hline 200 & 7 & 0.25 & 0 & - & 11.5 & - & 0.13 & 0.1 & 0.09 \\
\hline 200 & G & 0.25 & - & 0 & - & 11.5 & 0.12 & 0.095 & 0.083 \\
\hline Average: & & & & & & & 0.133 & 0.097 & 0.085 \\
\hline
\end{tabular}




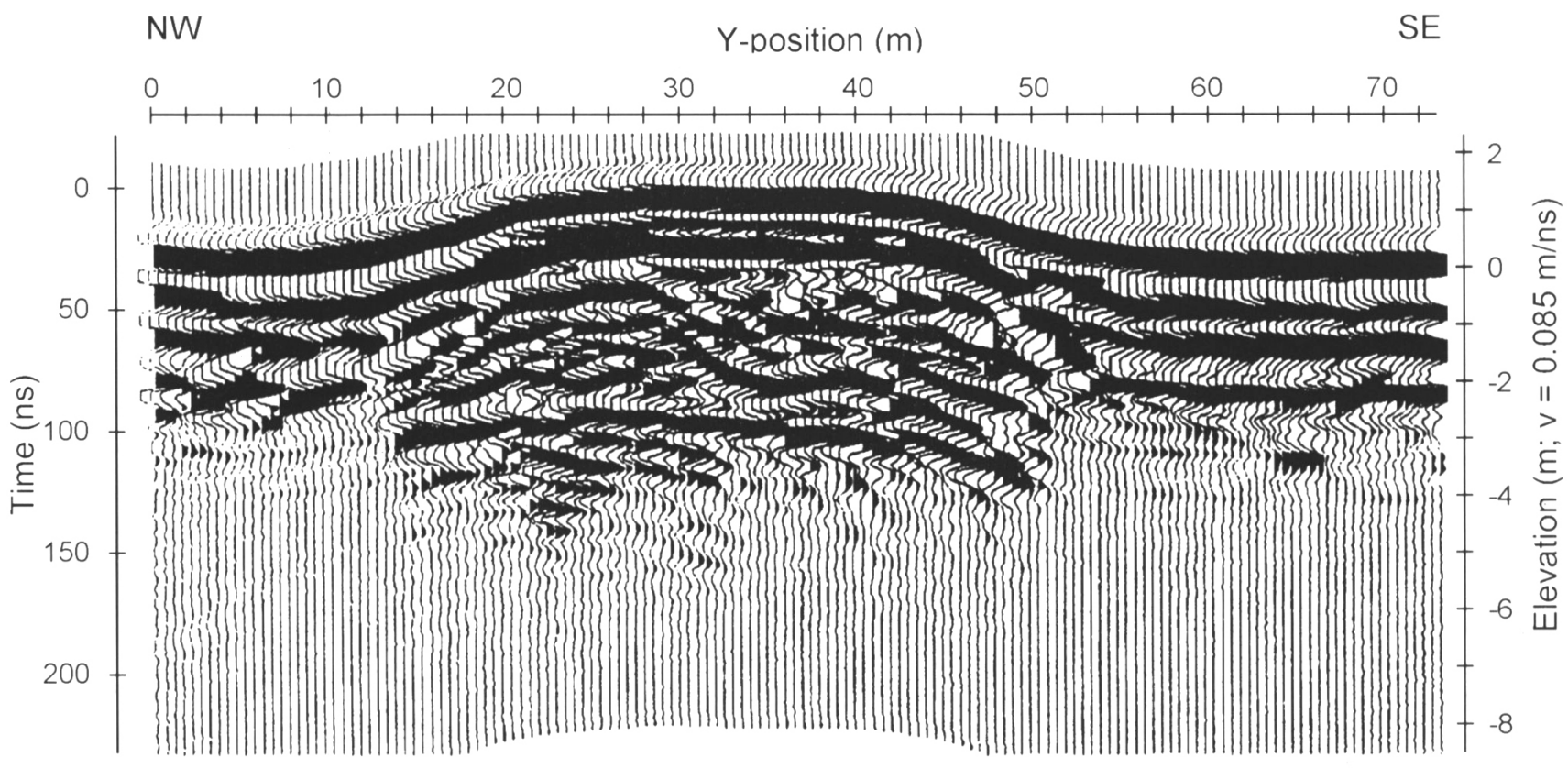

Fig. 5. Radar section $\mathrm{G}(100 \mathrm{MHz}$ ) showing differences in reflection pattern and penetration depth between low-conductive dune sands and more attenuative material (clay and peat) flanking the dune. Vertical exaggeration is around 3.2 .

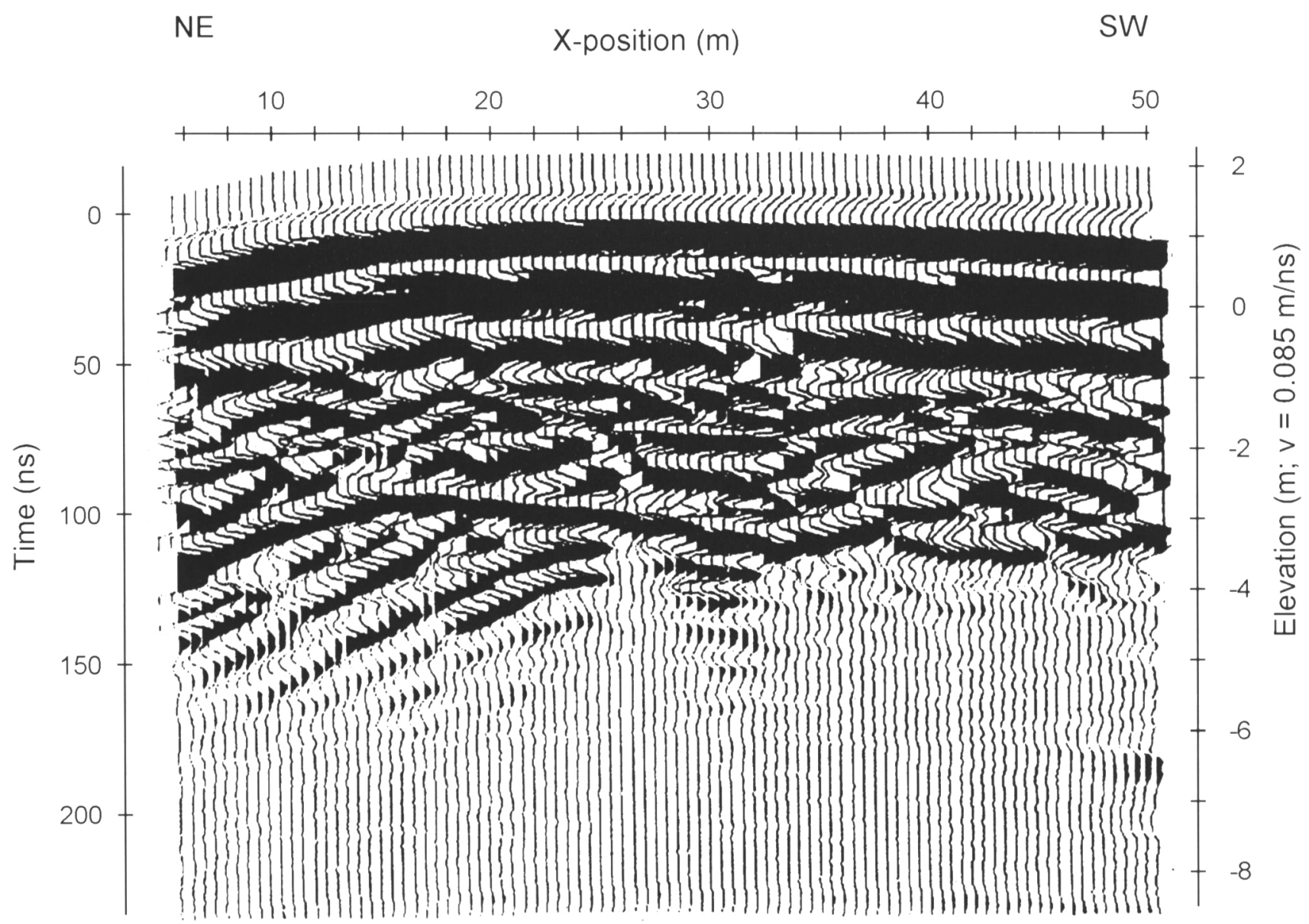

Fig. 6. Part of radar section $9(100 \mathrm{MHz})$ showing three different radar facies present in the dune: a) a lower unit with parallel, dipping reflectors, b) a highly continuous, sub-horizontal reflector (as middle unit), and c) a unit characterised by numerous discontinuous and sloping reflectors. Vertical exaggeration is around 3.2. 


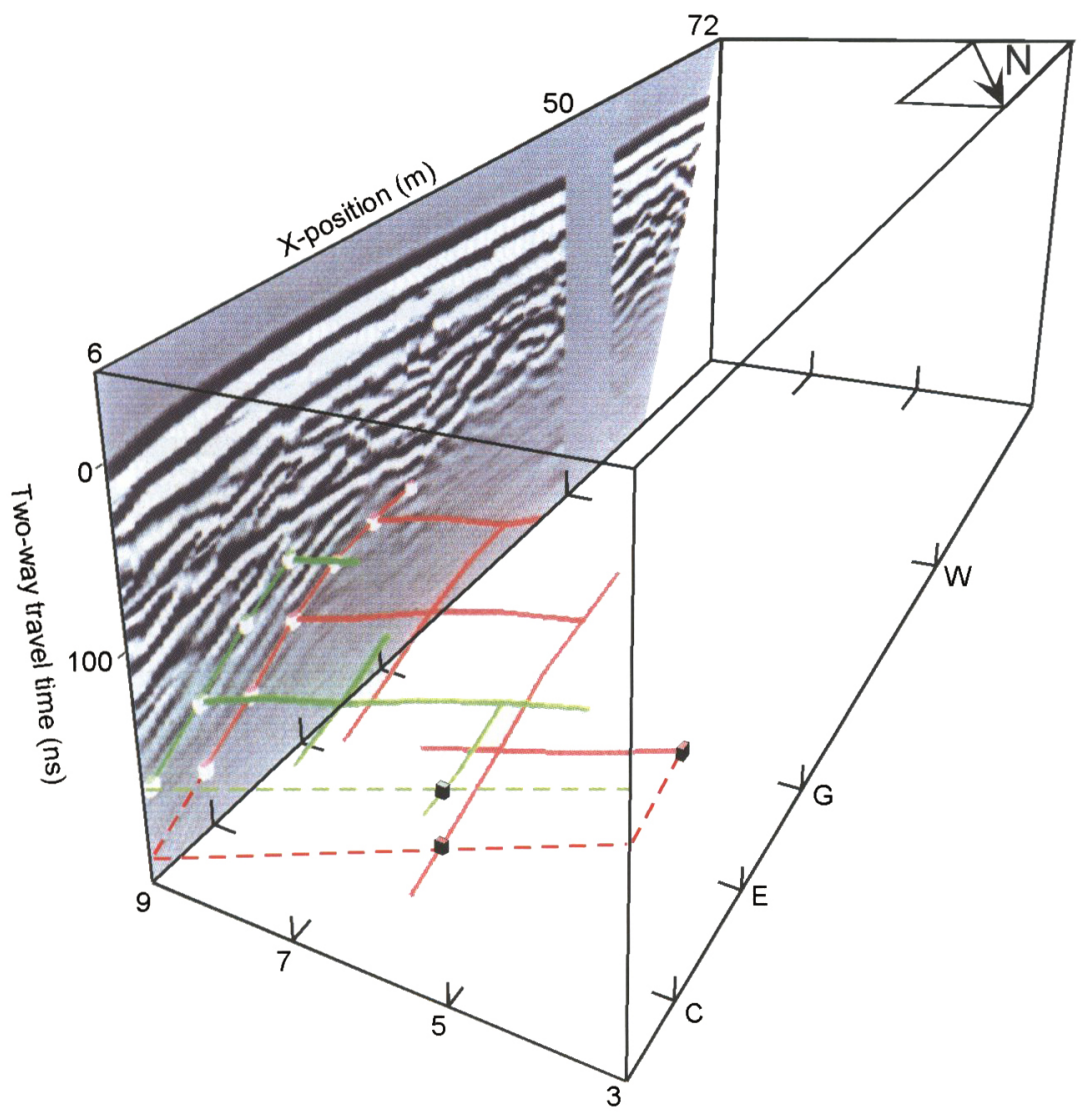

Fig. 7. Block diagram showing part of radar section $9(100 \mathrm{MHz})$, two (green and red) foresets interpreted using closed-loop correlation in GOCAD, and the location of other GPR sections. The white dots are 4-m spaced measurement points on dipping reflectors in GPR section 9 that were used to define the separate foresets. The dots mark the points were individual lines cross one of the cube planes. The dashed lines are projections of the foresets on the cube planes. The foresets dip roughly in an easterly direction.

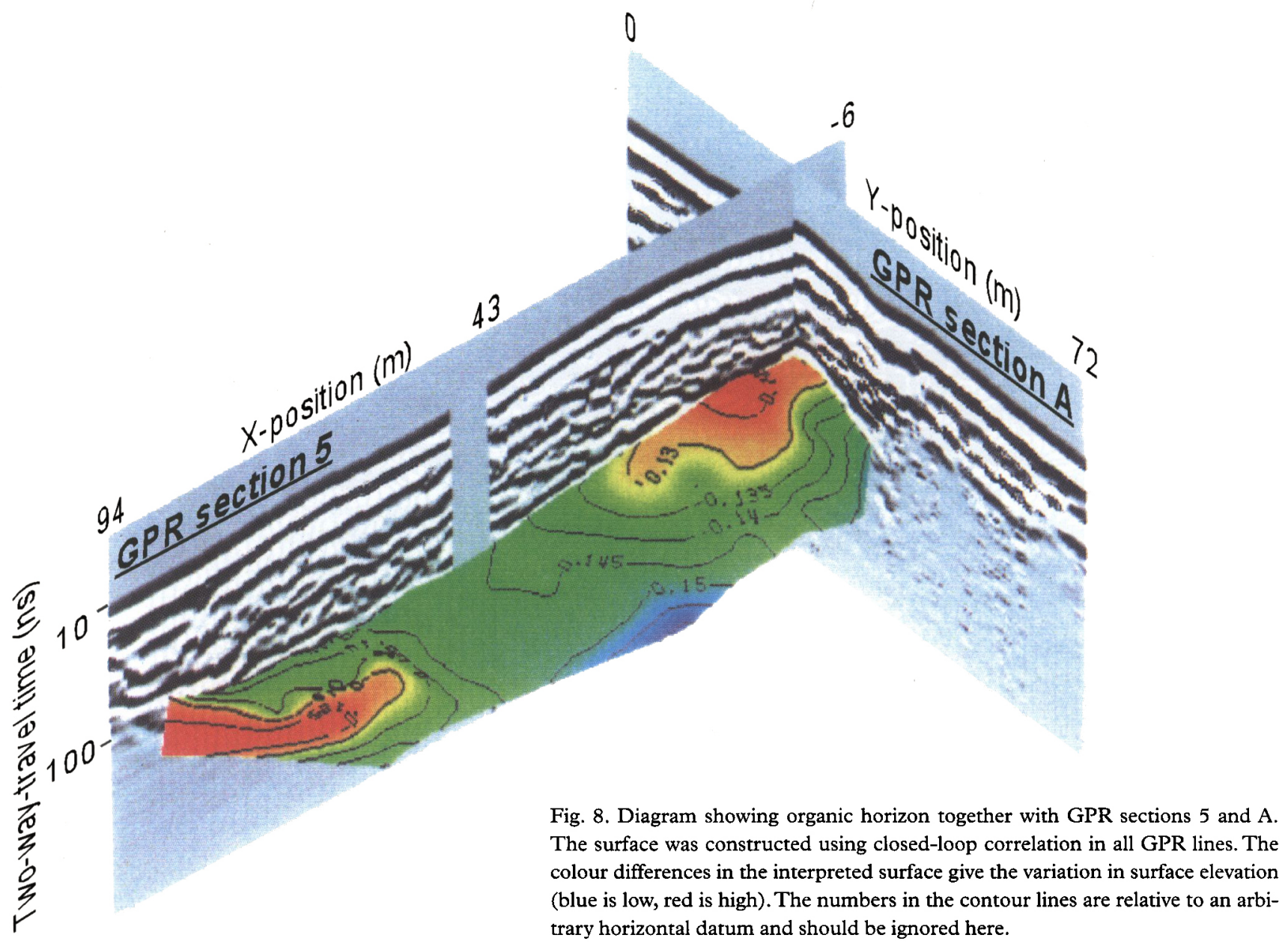




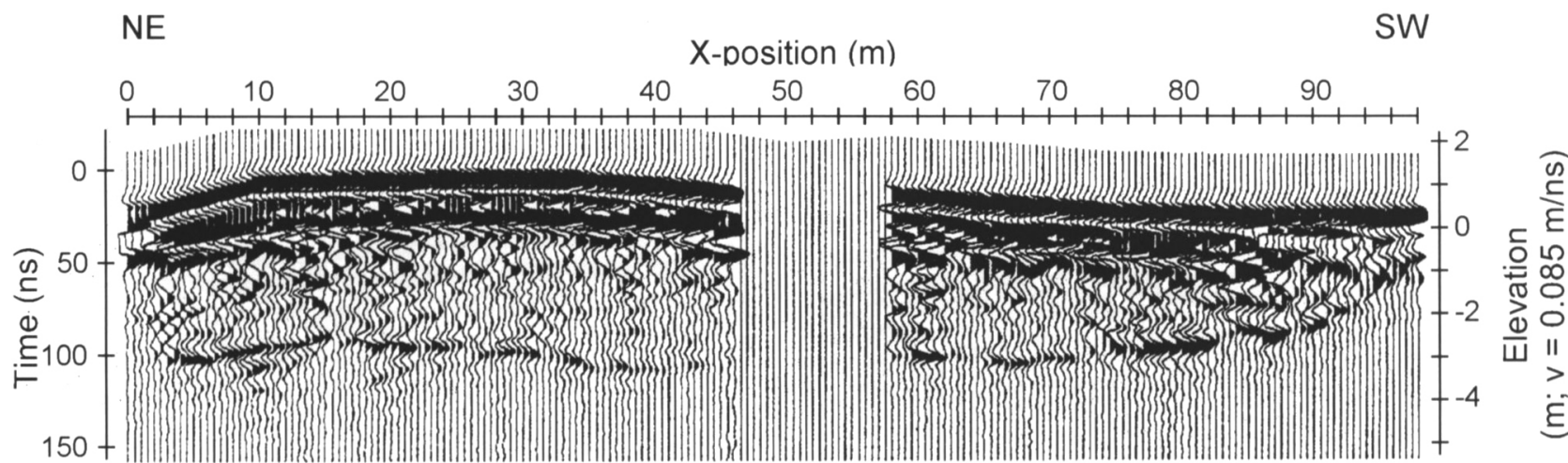

Fig. 9. Radar section $7(100 \mathrm{MHz})$ plotted with a spreading and exponential compensation (SEC) gain. A SEC gain compensates for spherical spreading losses and dissipation of energy but leaves relative amplitude differences intact. The image clearly shows that the amplitude of the reflection at approximately 100 ns two-way-travel time (twt) is larger than those of the reflections above and below. Vertical exaggeration is around 2.7 .

rich concretion found at a depth of $4 \mathrm{~m}$ in one of the auger drillings confirms that the reflector is a thin organic layer. This reflector is therefore interpreted to have formed by vegetation during a period of dune stabilisation.

\section{Radar facies 3}

The top unit of the dune is made up of discontinuous, dipping reflectors. The reflectors are highly variable in length ( 1 to $40 \mathrm{~m}$ ) and dip angle and dip direction. Most reflections are too short or unclear to allow correlation among different GPR sections. The facies unit is made up of two types of reflectors; relatively long $(>10 \mathrm{~m})$ and sub-horizontal reflectors versus rather short and steeper reflectors (Fig. 10). The amplitudes of the two reflector groups are similar, and they are interpreted as bounding surfaces separating sets of cross-stratification. The short reflections, associated with cross-stratification, predominantly dip in a easterly to north-easterly direction. The relatively chaotic reflection pattern of this facies unit as compared to radar facies 1 may suggest that the sediment deposition was influenced by vegetation.

\section{Dune development}

The organic horizon that was identified on the GPR sections implies that dune formation must have taken place in two phases. The unit below this hiatus (radar facies 1) with an approximate thickness of 5 to $6 \mathrm{~m}$ rests directly on top of the Wijchen Member clays and was most likely deposited during the Younger Dryas. Towards the east, the lee side of the dune dips very steeply from the land surface to its toe on the Wijchen Member, whereas towards the west, the stoss side of the dune dips gradually and can be tracked below the surface over a large distance (Louwe Kooijmans,
1974). This shows that the dune reached its maximum eastward position before stabilising here, and might explain the clear, eastward dipping, foresets present in the north-eastern part of the dune.

The sub-horizontal reflector (radar facies 2) marks the hiatus that separates two dune formation periods. During the Early Holocene, dune formation ceased as a result of increased vegetation cover. This vegetation was able to hold the sediment in place. Later during the Holocene, local dune reactivation caused erosion and deposition to form the top 3 to $4 \mathrm{~m}$ of the Hazendonk (radar facies 3 ). This reactivation probably occurred between around 9000 and $5000{ }^{14} \mathrm{C}$-years BP, as suggested by Pons (1957). Later in the Holocene, lower lying parts of the Hazendonk dune complex had already been covered by Holocene deposits so no sand would have been available for the formation of radar facies 3. More deposition was most likely to occur at places with dense vegetation. This might explain why the highest part of the Hazendonk lies almost directly above the lowest part of the vegetation horizon (see Fig. 8), with a little eastward (downwind) shift. Here, a relatively high groundwater table possibly had enabled a well developed plant cover. The sediment in this unit was deposited by a series of small dunes with predominantly eastward to northeastward dipping foresets, partly eroding older ones. This partial erosion of previous deposits led to the development of the bounding surfaces that are visible in the GPR sections.

Although the amount of information is rather sparse, the dip directions of the reflections in radar facies 1 and 3 suggest a shift in predominant wind direction from westerly in the Younger Dryas to westsouth-westerly in the Early Holocene. To verify this theory, GPR should be used to image sedimentary structures in other (aeolian river) dunes and to analyse their dip directions. 

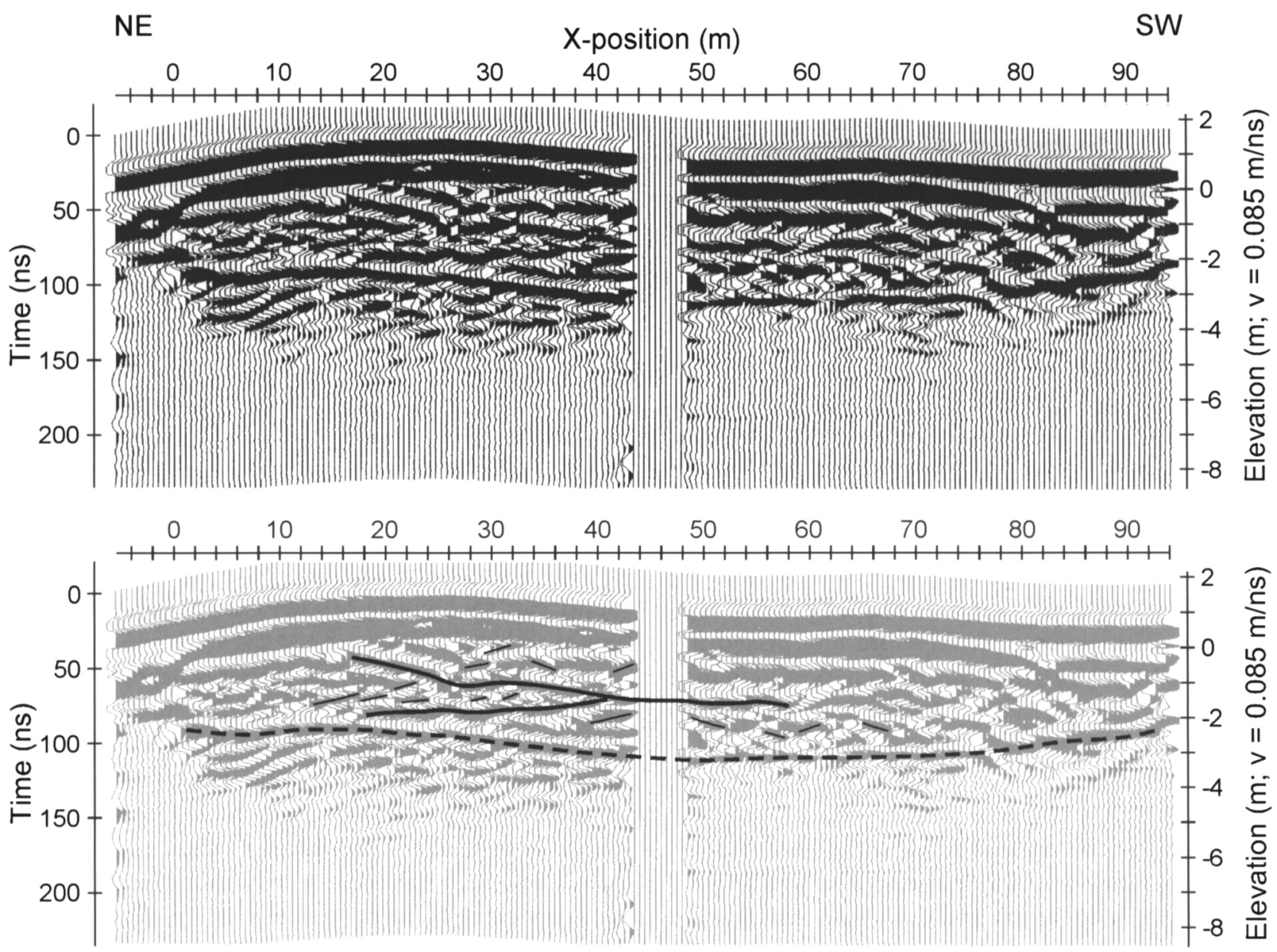

Fig. 10. Diagram showing GPR section $5(100 \mathrm{MHz})$ and interpretation of radar facies 3. Vertical exaggeration is around 3.2. The dashed line represents the organic horizon (radar facies 2) that marks the lower boundary of radar facies 3 . The unit consists of sets of short and dipping reflectors (thin lines), interpreted as foresets, separated by relatively long and sub-horizontal reflectors (thick lines), interpreted as bounding surfaces.

\section{Conclusions}

This paper started with the observation that the nondestructive geophysical GPR technique can play an important role in the characterisation of aeolian deposits. In this study, 3-D imaging of a GPR grid has been used to interpret a buried 9-m high aeolian river dune in The Netherlands. Three radar facies are identified, which together tell the story of the development of the dune. The lowermost unit with a thickness of 5 to $6 \mathrm{~m}$ is characterised by parallel, dipping reflections of eastward-dipping foresets of the dune. This unit was deposited in the Younger Dryas under prevailing westerly winds. The middle unit is one subhorizontal and continuous reflection, present in all the GPR sections. The large reflection amplitude, relative to the amplitudes in the units above and below, as well as the morphology of the reflector suggest that the unit is a stabilisation surface. Drilling results confirm that the high impedance contrast of this reflector is caused by the presence of organic matter in a thin horizon, which can be attributed to vegetation that stabilised the dune surface during the Early Holocene. The topmost unit has a thickness of 3 to 4 $\mathrm{m}$ and is characterised by short reflections, which predominantly dip in easterly to north-easterly direction, separated by longer, sub-horizontal reflections. Small dunes deposited on top of the vegetation horizon led to this configuration of cross-stratification and bounding surface reflections. The results suggest a small shift in wind direction from westerly in the Younger Dryas to west-south-westerly in the Early Holocene, but more data are essential to confirm this theory.

\section{Acknowledgements}

I thank Josef Reckman and Joep Storms who assisted during the fieldwork, Berend Scheffers who helped with Promax and GOCAD, and Wim Immers who drew several of the figures. I am greatly indebted to Ronnie Van Overmeeren who was instrumental in all 
parts of the project. Except for JS all are from the Netherlands Institute of Applied Geoscience TNO. An early version of the manuscript benefited from comments by Charlie Bristow (University of London) and from discussions with Torbjörn Törnqvist (University of Illinois at Chicago) and Joep Storms (Technical University Delft). I acknowledge the reviewers Philip Gibbard (University of Cambridge) and Sytze van Heteren (Netherlands Institute of Applied Geoscience TNO), as well as Kees Kasse (Vrije Universiteit Amsterdam) for their useful suggestions to improve the paper.

\section{References}

Ahlbrandt, T.S. \& Fryberger, S.G., 1980. Aeolian deposits in the Nebraska Sand Hills. U.S. Geological Survey Professional Paper 1120A: 1-24.

Anderson, M.P., Aiken, J.S., Webb, E.K. \& Mickelson, D.M., 1999. Sedimentology and hydrogeology of two braided stream deposits. Sedimentary Geology 129: 187-199.

Asprion, U. \& Aigner, T., 1999. Towards realistic aquifer models: three-dimensional georadar surveys of Quaternary gravel deltas (Singen Basin, SW Germany). Sedimentary Geology 129: 281 . 297.

Berendsen, H.J.A., Hoek, W.Z. \& Schorn, E.A., 1995. Late Weichselian and Holocene river channel changes of the rivers Rhine and Meuse in the central Netherlands (Land van Maas en Waal). In: Frenzel, B. (ed.): ESF Project European Palaeoclimate and Man. Paläoklimaforschung: 151-171.

Beres, M., Huggenberger, P., Green, A.G. \& Horstmeyer, H., 1999. Using two- and three-dimensional georadar methods to characterize glaciofluvial architecture. Sedimentary Geology 129: 1-24.

Bridge, J.S., Alexander, J., Collier, R.E.L., Gawthorpe, R.L. \& Jarvis, J., 1995. Ground-penetrating radar and coring used to study the large-scale structure of point-bar deposits in three dimensions. Sedimentology 42: 839-852.

Bristow, C.S., 1995. Internal geometry of ancient tidal bedforms revealed using gpr. International Association of Sedimentologists Special Publication 24: 313-328.

Bristow, C.S., Bailey, S.D. \& Lancaster, N., 2000a. The sedimentary structure of linear sand dunes. Nature 406: 56-59.

Bristow, C.S., Chroston, P.N. \& Bailey, S.D., 2000b. The structure and development of foredunes on a locally prograding coast: insights from ground-penetrating radar surveys, Norfolk, UK. Sedimentology 47: 923-944.

Bristow, C.S., Pugh, J. \& Goodall, T., 1996. Internal structure of aeolian dunes in Abu Dhabi determined using ground-penetrating radar. Sedimentology 43: 995-1003.

Daniels, D.J., Gunton, D.J. \& Scott, H.E., 1988. Introduction to subsurface radar. IEE Proceedings 135: 278-320.

Davis, J.L. \& Annan, A.P., 1989. Ground-penetrating radar for high resolution mapping of soil and rock stratigraphy. Geophysical Prospecting 37: 531-551.

Dix, C.H., 1955. Seismic velocities from surface measurements. Geophysics 20: 68-86.

Gawthorpe, R.L., Collier, R.E.L., Alexander, J., Leeder, M.R. \& Bridge, J.S., 1993. Ground penetrating radar: application to sandbody geometry and heterogeneity studies. In: North, C.P. \& Prosser, D.J. (eds.): Characterisation of fluvial and aeolian reservoirs. Geological Society (London): 421-432.
Huggenberger, P., 1993. Radar facies: recognition of facies patterns and heterogeneities within Pleistocene Rhine gravels, NE Switzerland. In: Best, J.L. \& Bristow, C.S. (eds): Braided Rivers: Geological Society (London): 163-176.

Isarin, R.F.B., Renssen, H. \& Koster, A., 1997. Surface wind climate during the Younger Dryas in Europe as inferred from aeolian records and model simulations. Palaeogeography Palaeoclimatology Palaeoecology 134: 127-147.

Jol, H.M. \& Smith, D.G., 1991. Ground penetrating radar of northern lacustrine deltas. Canadian Journal of Earth Sciences 28: 1939-1947.

Louwe Kooijmans, L.P., 1974. The Rhine/Meuse delta. Four studies on its prehistoric occupation and Holocene geology. Ph.D. Thesis, Leiden University (Leiden): $421 \mathrm{pp}$.

McKee, E.D., 1966. Structures of dunes at White Sands National Monument, New Mexico (and a comparison with structures of dunes from other selected areas). Sedimentology 7: 1-69.

McKee, E.D. \& Bigarella, J.J., 1979. Sedimentary structures in dunes with two sections on the Lagoa dune field, Brazil. In: McKee, E.D. (ed.): A study of global sand seas. U.S. Geological Survey: 83-136.

McMechan, G.A., Gaynor, G.C. \& Szerbiak, R.B., 1997. Use of ground-penetrating radar for 3-D sedimentological characterisation of clastic reservoir analogs. Geophysics 62: 786-796.

Pedley, H.M., Hill, I., Denton, P. \& Brasington, J., 2000. Three-dimensional modelling of a Holocene tufa system in the Lathkill Valley, north Derbyshire, using ground-penetrating radar. Sedimentology 47: 721-737.

Pons, L.J., 1957. De geologie, de bodemvorming en de waterstaatkundige ontwikkeling van het Land van Maas en Waal en een gedeelte van het Rijk van Nijmegen. Ph.D. Thesis, Wageningen University (Wageningen): $156 \mathrm{pp}$.

Schenk, C.J., Gautier, D.L., Olhoeft, G.R. \& Lucius, J.E., 1993. Internal structure of an aeolian dune using ground-penetrating radar. International Association of Sedimentologists Special Publication 16: 61-69.

Törnqvist, T.E., 1998. Longitudinal profile evolution of the RhineMeuse system during the last glaciation: interplay of climate change and glacio-eustasy? Terra Nova 10: 11-15.

Törnqvist, T.E., Weerts, H.J.T. \& Berendsen, H.J.A., 1994. Definition of two new members in the upper Kreftenheye and Twente Formations (Quaternary, The Netherlands): a final solution to persistent confusion? Geologie en Mijnbouw 72: 251-264.

Van Dam, R.L., 2001. Causes of ground-penetrating radar reflections in sediment. Ph.D. Thesis, Vrije Universiteit (Amsterdam): $110 \mathrm{pp}$.

Van Dam, R.L. \& Schlager, W., 2000. Identifying causes of groundpenetrating radar reflections using time-domain reflectometry and sedimentological analyses. Sedimentology 47: 435-449.

Van Dam, R. L., Van Den Berg, E. H., Van Heteren, S., Kasse, C., Kenter, J. A. M. \& Groen, K., 2002. Influence of organic matter on radar-wave reflection: sedimentological implications. Journal of Sedimentary Research 72(3): 341-352.

Van Heteren, S., Fitzgerald, D.M., McKinlay, P.A. \& Buynevich, I.V., 1998. Radar facies of paraglacial barrier systems: coastal New England, USA. Sedimentology 45: 181-200.

Van Overmeeren, R.A., 1998. Radar facies of unconsolidated sediments in The Netherlands: A radar stratigraphy interpretation method for hydrogeology. Journal of Applied Geophysics 40: 118.

Verbraeck, A., 1983. Sedimentation in the mid-Netherlands river area during the Late Weichselian. Geologie en Mijnbouw 62: 487-491. 